\title{
Pengabdian Kepada Masyarakat: Pengenalan Flipped Learning bagi Guru di Madrasah Ibtidaiyah
}

\author{
Irfan Fajrul Falah ${ }^{1 *}$, Dodi Ahmad Haerudin ${ }^{2}$ \\ 1,2 STKIP Muhammadiyah Kuningan \\ Email: irfan_fajrul@upmk.ac.id; dodi@upmk.ac.id \\ *Corresponding author; irfan_fajrul@upmk.ac.id ${ }^{1}$
}

\begin{abstract}
ABSTRAK
Pandemi Covid-19 memberikan dampak yang sangat besar terhadap aspek-aspek kehidupan terutama aspek pendidikan di tingkat sekolah dasar. Dalam upaya mencari model pembelajaran yang cocok dan relevan dengan karakteristik siswa, flipped learning hadir sebagai salah satu model pembelajaran alternatif yang dapat di implementasikan dalam kondisi yang serba terbatas seperti ini. Pengenalan flipped learning sendiri menjadi tujuan utama dalam pengabdian kepada masyarakat ini agar kesempatan sekolah yang dalam hal ini Madrasah Ibtidaiyah memiliki kesempatan yang sama untuk mengembangkan pembelajaran yang efektif. Pengabdian ini berlangsung selama dua hari dimana pada hari pertama fokus perhatian ditujukan pada pengenalan flipped learning secara teori. Adapun dalam pengabdian ini juga peserta pelatihan diberikan kesempatan utuk mendesain video pembelajaran yang akan digunakan. Setelah semua komponen pembelajaran siap, guru di madrasah didampingi untuk mengimplementasikan flipped learning. adapun hasil yang didapat adalah berupan peningkatan pengetahuan guru tentang flipped learning terlihat dari rata-rata hasil pre-test yakni 40 menjadi 70 pada post-test atau meningkat $30 \%$. Hasil yang didapat tentu tidak hanya peningkatan pengetahuan guru tentang siswa, melainkan juga pengalaman baru baik bagi siswa dan juga guru agar pembelajaran lebih efektif dan dinamis.
\end{abstract}

Kata Kunci: flipped learning; implementasi; madarasah ibtidaiyah

\begin{abstract}
ABSTRACK
Covid-19 Pandemic has affected almost every aspect of life, not to mention education especially in primary level. in search of a fit and suitable learning model, flipped learning appeared to be one of alternative and seems aplicable during this period. The introduction of flipped learning in primary school is the main purpose of this community service program. Thus, the school teachers particularly in Madrasah Ibtidaiyah have the same opportunity to develop an effective teaching and learning. this program was organized in two days where the theory of flipped learning and everything its implementation including designing lesson plan and creating a learning video. The result shows that this model that implemented increased not only students' engagement but teachers' knowledge as indicated from from 40 in pre-test to 70 in post-test or around $30 \%$ of improvement..
\end{abstract}

Keywords: flipped learning; implemenetation; madrasah ibtidaiyah 
PENDAHULUAN

Penyebaran Corona Virus

Disease (COVID-19) yang tak kunjung mereda, memberikan dampak yang sangat besar terhadap aspek-aspek kehidupan terutama pada aspek pendidikan (Kemendikbud, 2020) Masih banyak sekolah terutama di tingkat sekolah dasar yang mengalami kesulitan dan terus mencari bentuk terbaik dari pembelajaran daring yang diselenggarakan (Lestari \& Gunawan, 2020). Hal ini dilakukan tidak lain agar tujuan pembelajaran bisa dicapai dan juga pengetahuan siswa terhadap materi bisa terbentuk. Karena bagaimanapun, siswa memiliki hak untuk mendapatkan pembelajaran yang maksimal terlepas dari apa dan bagaimana bentuk pembelajaran yang diselenggarakan oleh guru .

\section{Di Kecamatan}

Cigandamekar Kabupaten

Kuningan Jawa Barat, terdapat kurang lebih tujuh (7) Madrasah Ibtidaiyah yang juga melakukan proses pembelajaran adaptif baik secara daring maupun luring selama pandemi. Namun pada kenyataanya mayoritas guru yang mengajar mengaku kesulitan untuk menciptakan pembelajaran yang dinamis, interaktif dan juga efektif. Hal ini tentu disebabkan oleh banyak faktor yang salah satunya adalah guru kurang berani untuk melakukan inovasi serta improvisasi pembelajaran. Padahal banyak sekali model pembelajaran yang bisa digunakan dan sangat mendukung untuk menciptakan pembelajaran yang tidak hanya menrik tetapi juga bermakna bagi siswa. Misalnya saja model pembelajaran flipped learning yang memadukan pembelajaran secara online (daring) dan juga tatap muka yang terbatas (luring) (Turan \& Akdag-cimen, 2019).

Flipped learning sendiri merupakan sebuah pendekatan pedagogis dimana instruski pembelajaran yang biasa disampaikan kepada siswa secara grup berpidah menjadi kepada siswa secara individu (Bergmann \& Sams, 2012; Flipped Learning Network, 2014). Dengan model seperti ini, tidak hanya memberikan kesempatan kepada siswa untuk mengeksplorasi kemampuan sesuai dengan kapasitas, waktu dan juga preferensi gaya belajar mereka, akan tetapi learning engagement ketika siswa berada di in-class activity juga akan semakin tinggi (Cheung, Yang, \& Chen, 2019) dikarenakan siswa sudah memiliki pengetahuan awal ketika mereka mempelajari materi atau video yang dibagikan oleh guru sebelum pembelajaran di kelas.

$\begin{array}{cr}\text { Berkaitan } & \text { dengan } \\ \text { kurangnya eksplorasi guru }\end{array}$ terhadap model pembelajaran yang dapat diimplementasikan dimasa pandemi, tim pengabdian tergerak untuk melakukan pengabdian kepada masyarakat (PKM). Adapun jenis pengabdian sendiri berbentuk pelatihan dimana pengenalan flipped learning menjadi fokus utama. Tujuan dari PKM ini adalah untuk mengenalkan model flipped 
learning sehingga guru madrasah ibtidaiyah di Kecamatan Cigandamekar dapat mengimplementasikannya dan menjadi alternatif untuk menciptakan active learning dan joyfull learning.

\section{METODE PELAKSANAAN}

Metode pelaksanaan kegiatan dibagi kedalam tiga langkah yakni perencanaan, pelaksanaan dan evaluasi. Adapun tahapan atau langkahlangkah tersebut dapat dilihat pada gambar berikut :

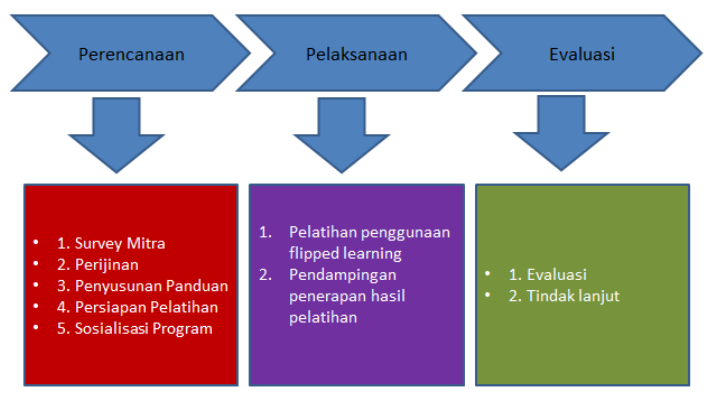

Gambar 1.

Tahapan pelaksanaan

$\begin{aligned} & \text { Pada tahap pelaksanaan } \\ & \text { kegiatan, } \text { pelatihan yang }\end{aligned}$ dilaksanakan diikuti oleh kurang lebih 14 guru dari 7 MI atau 2 guru dari masing-masing madrasah. Hal tersebut dilakukan agar protokol kesehatan senantiasa dapat dijaga dengan tidak berkerumun dalam sebuah ruangan. Pelatihan sendiri diselenggarakan selama 2 hari (22-23 Juli 2021) bertempat di Madrasah Ibtidaiyah Bhakti Buana Sangkanhurip. Adapun setelah pelatihan dilaksanakan, tim pengabdian melakukan tindak lanjut yakni dengan memberikan dampingan kepada madarasah dalam mengimplementasikan flipped learning.

HASIL DAN PEMBAHASAN

Pelatihan flipped learning yang diselenggarakan dimulai dengan pre-tes tentang pengetahuan awal guru mengenai flipped learning. dalam pre-test ini terdapat 10 pertanyaan yang harus dijawab oleh peserta pelatihan. Adapun pertanyaanpertanyaan tersebut meliputi definisi, kelebihan, langkahlangkah serta karakteristik model pembelajaran flipped learning.

Berdasarkan hasil pre-tes yang dilakukan, rata-rata peserta mendapatkan nilai 40. Hal tersebut dikarenakan para guru belum mengenal flipped learning. Misalnya saja, salah satu peserta (G9) mengakui bahwa dia sama sekali tidak mengetahui apa itu flipped learning.

G1 mengungkapkan pernah mempelajari namun belum berani untuk mengimplementasikan dikarenakan ingin dalam implementasinya maksimal menggunakan video pembelajaran yang dibuat sendiri. Walaupun, untuk penggunaan video ataupun materi dalam flipped learning bisa mengunakan video yang sudah tersedia di platform online dan tidak harus berbentuk video. Bisa juga bahan bacaan dan juga tugas yang diberikan oleh guru. Adapun 
keseluruhan hasil pre-tes dan post-tes dapat dilihat pada tabel berikut ini :

\begin{tabular}{|l|l|l|l|}
\hline No & Nama & $\begin{array}{l}\text { Pre- } \\
\text { tes }\end{array}$ & $\begin{array}{l}\text { Post- } \\
\text { tes }\end{array}$ \\
\hline 1 & G1 & 60 & 80 \\
\hline 2 & G2 & 50 & 70 \\
\hline 3 & G3 & 30 & 70 \\
\hline 4 & G4 & 50 & 70 \\
\hline 5 & G5 & 40 & 80 \\
\hline 6 & G6 & 40 & 60 \\
\hline 7 & G7 & 40 & 80 \\
\hline 8 & G8 & 30 & 70 \\
\hline 9 & G9 & 30 & 50 \\
\hline 10 & G10 & 30 & 60 \\
\hline 11 & G11 & 30 & 70 \\
\hline 12 & G12 & 40 & 80 \\
\hline 13 & G13 & 50 & 70 \\
\hline 14 & G14 & 40 & 70 \\
\hline & Average & 40 & 70 \\
\hline
\end{tabular}

Tabel 1. Hasil pre dan post-tes

Berdasarkan pada tabel 1 , dapat dilihat bahwa pengetahuan guru berkaitan dengan flipped learning meningkat 30 poin dimana ketika pre-test rata-rata guru berada pada angka 40 menjadi 70 setelah mengikuti pelatihan flipped learning. Hal ini tentu menunjukan bahwa ketika guru disekolah dasar diberikan kesempatan untuk mengembangkan pengetahuannya, mereka bisa memanfaatkannya dengan baik.

Selain mengukur pengetahuan guru berkaitan dengan flipped learning, dalam pengabdian kepada masyarakat ini juga diajarkan kepada guru untuk membuat video pembelajaran dengan menggunakan aplikasi sederhana seperti Kinemaster dan juga VivaVideo. Pembuatan video pembelajaran tersebut yang dibuat secara mandiri oleh guru tentu akan sangat menunjang implementasi flipped learning. (Bergmann \& Sams, 2015) merekomendasikan bahwa setiap guru khususnya di tingkat sekolah dasar untuk membuat video atau menyusun materi secara mandiri. Hal ini akan membuat siswa tertarik karena apa yang mereka lihat dan saksikan adalah guru mereka. Berbeda ketika yang mereka simak adaah orang lain tentu chemistry-nya akan berbeda.

Dalam proses pembuatan video pembelajaran tersebut, para peserta didampingi juga oleh mahasiswa yang sengaja dilibatkan dalam kegiatan pengabdian ini. Video pembelajaran sendiri tentu tidak langsung jadi dalam sehari. Terdapat proses-proses yang harus dilalui oleh peserta misalnya pembuatan skenario yang tentu akan sangat membantu peserta pelatihan dalam mengembangkan video pembelajaran yang mereka inginkan (Susanti \& Hamama Pitra, 2019). Pembuatan skenario sendiri disesuaikan dengan tema dan juga materi yang belum diajarkan. Hal ini menjadi moivasi tersendiri agar ketika 
video pembelajaran selesai dibuat dapat digunakan di kelas masingmasing sebagai output dari pelatihan yang diselenggarakan.

Setelah skenario selesai dibuat, langkah berikutnya yang harus dilakukan adalah "taking" atau pengambilan klip. Pada kesempatan ini, peserta menggunakan perangkat masingmasing seperti kamera baik itu dari handphone ataupun eksternal kamera, earphone dan juga lighting sederhana. Termasuk juga pada sesi ini, peserta direkomendasikan untuk memanfaatkan green screen agar nanti hasilnya maksimal.

Setelah semua kebutuhan untuk membuat video pembelajaran didapat, di hari kedua, peserta mengedit dan mengkompilasi klip yang mereka sudah ambil kedalam aplikasi video editing seperti Kinemaster dsb. Melalui aplikasi tersebut, peserta dapat menambahkan fiturfitur yang tersedia sehingga membuat tampilan video pembelajaran semakin menarik dan dapat disesuaikan dengan kebutuhan materi.

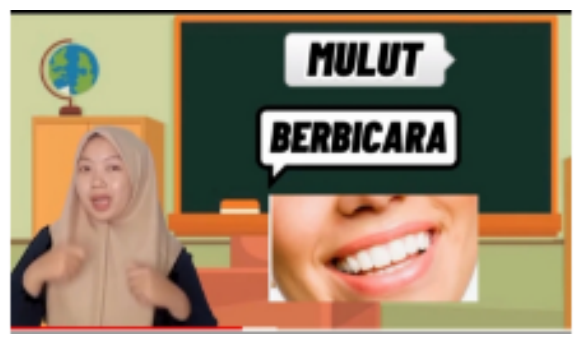

Gambar 2.

Contoh video pembelajaran
Proses editing sendiri menjadi proses yang paling memakan waktu. Selain detail dari video, transisi antar klip juga menjadi hal yang harus diperhatikan (Yudasmara \& Purnami, 2015). Transisi tersebut harus dibuat serapih mungkin agar siswa yang nanti akan menyaksikan dan melihat video pembelajaran tidak terganggu dan juga lebih memudahkan mereka dalam mencerna materi yang disampaikan. Setelah proses editing selesai, tentu proses berikutnya adalah uploading hasil pelatihan berupa video pembelajaran ke youtube masingmasing sekolah atau masingmasing guru.

Tahapan berikutnya yang terdapat dalam pengabdian kepada masyarakat ini adalah pendampingan. Dikarenakan waktu dan kondisi yang kurang memungkinkan, pendampingan implementasi sendiri hanya berlangsung di satu sekolah yakni MI Bhakti Buana Sangkanhurip. Disamping itu, partisipan dari sekolah tersebut juga menghasilkan video pembelajaran yang menarik sehingga kemungkinan untuk bisa diimplementasikan dalam pemberlajaran tatap muka semakin besar.

Proses pendampingan sendiri berlangsung selama dua hari dimana di hari pertama di MI Bhakti Buana Sangkahurip, guru 
dan juga tim pengabdian berdiskusi untuk merancang RPP dan juga mendistribusikan video pembelajaran melalui WhatsApp grup kelas V seperti kebanyakan guru di kelas dan sekolah lainnya (Susanti \& Hamama Pitra, 2019). Tidak hanya video, dalam WhatsApp grup tersebut guru juga memberikan tugas yang harus dikerjakan sebelum mereka bertatap muka seperti konsep flipped learning yang dikemukakan oleh (Bergmann \& Sams, 2012). Adapun tugas tersebut diarahkan agar siswa bisa memahami materi. Misalnya saja guru dalam tugas tersebut memberikan pertanyaan "apa yang kalian temukan dalam video tersebut?". Pertanyaan ini tentu menjadi patokan siswa untuk mencermati video yang di bagikan.

Pada hari kedua pendampingan, siswa diberikan kesempatan untuk bertatap muka walaupun terbatas dan menerapkan protokol kesehatan di kelas dengan ibu gurunya. Diawal pembelajaran seperti biasa anakanak berinteraksi mengucapkan salam dan bertegur sapa dengan rekan-rekannya. Setelah itu guru memastikan siap-siapa saja siswa yang mengerjakan dan melihat video pembelajaran yang dikirimkan. Hal ini dilakukan agar guru merasa yakin dan siswa juga berada dalam kondisi siap untuk tindak lanjut video pembelajaran yang dibagikan sebelumnya.

Sejumlah 15 siswa di kelas V MI Bhakti Buana Sangkanhurip lalu dibagi kedalam lima kelompok secara heterogen. Dalam kelompok tersebut siswa berdiskusi dengan teman terkait materi yang dibagikan dalam video. Siswa juga diarahkan untuk membuat ringkasan hasil diskusi mereka sebelum perwakilan setiap kelompok mempresentasikan hasil diskusinya. Proses diskusi sendiri berlangsung secara interaktif karena masing-masing siswa sudah mempunyai bahan yang didapat sebelum pembelajaran tatap muka berlangsung melalui video.

Setelah diskusi selesai, masing-masing perwakilan kelompok mempresentasikan hasil diskusi mereka di depan kelas. Tidak hanya itu masingmasing kelompok yang memperhatikan juga diberikan kesempatan untuk bertanya berkaitan dengan presentasi yang disampaikan. Proses ini juga tentu sangat berguna untuk mengembangkan keterampilan komunikasi siswa yang memang sangat dibutuhkan. Setelah siswa selesai melakukan presentasi, guru melakukan refleksi dan juga menambahkan hal-hal yang berkaitan dengan materi yang belum sempat disampaikan oleh kelompok. 
Di akhir sesi, guru dan juga tim pengabdi merefleksikan flipped learning yang sudah diimplementasikan. Dalam momen ini juga guru meyampaikan kesulitan, tantangan dan juga pengalaman yang dialami. Tentu dari hal tersebutlah perbaikan akan senantiasa dilakukan, karena bagaimanapun dampak dari flipped learning ini tidak bisa terlihat dari satu atau dua kali tatap muka melainkan melalui proses yang berkelanjutan.

\section{SIMPULAN}

Kegiatan pengabdian yang diselenggarakan ini memberikan dampak yang signifikan kepada guru sehingga dapat meningkatkan kualitas pembelajaran di madrasah Ibtidaiyah. Hal tersebut terlihat dari hasil pre-test dan post-test yang meningkat sekitar $30 \%$. Walaupun demikian, pengembangan harus senantiasa dilakukan agar pembelajaran aktif, efektif dan dinamis bisa dicapai.

\section{DAFTAR PUSTAKA}

Bergmann, J., \& Sams, A. (2012). Flipped Your Classroom : Reach Every Students in Every Class Every day. In International Society for Technology in Education.

Bergmann, J., \& Sams, A.
(2015). Flipped Learning for Elementary Instruction. In International Society for Technology in Education. https://doi.org/10.4135/9781 483318332.n193

Cheung, C., Yang, R., \& Chen, Y. (2019). Implementing the flipped classroom approach in primary English classrooms in China. Education and Information Technologies. https://doi.org/10.1007/s106 39-019-10012-6

Flipped Learning Network. (2014). What Is Flipped Learning? The Four Pillars of F-L-I-P. Flipped Learning Network, 501(c), 2. Retrieved from http://www.flippedlearning. org/definition

Kemendikbud. (2020). Surat Edaran Nomor 3 Tahun 2020 Tentang Pencegahan Corona Virus Disease (Covid-19) Pada Satuan Pendidikan. 1-5. Retrieved from https://www.kemdikbud.go.i d/main/blog/2020/03/suratedaran-pencegahancovid19-pada-satuanpendidikan

Lestari, P. A. S., \& Gunawan. (2020). The Impact of Covid 19 Pandemic on Learning Implementation of Primary and Secondary School Level. Indonesia Journal of Elementary and Childhood Education, 1(2), 858-863. Susanti, L., \& Hamama Pitra, D. A. (2019). Flipped Classroom Sebagai Strategi Pembelajaran Pada Era 
Digital. Health \& Medical

Journal, 1(2), 54-58.

https://doi.org/10.33854/he

me.v1i2.242

Turan, Z., \& Akdag-cimen, B.

(2019). Flipped classroom in

English language teaching :

a systematic review.

Computer Assisted

Language Learning, O(0),

1-17.

https://doi.org/10.1080/0958

8221.2019 .1584117

Yudasmara, G. A., \& Purnami,

D. (2015). Pengembangan

Media Pembelajaran SMP.

Jurnal Pendidikan Dan

Pengajaran, 48(1), 1-8. 